\title{
Representations of the Alternative Press in Academic Library Collections
}

\section{Rita A. Marinko and Kristin H. Gerhard}

\begin{abstract}
This study uses the list of periodicals indexed by Alternative Press Index to examine the holdings rates of alternative press titles in U.S. ARL libraries. Holdings rates are examined by library, by title, and by subject category. Alternative press titles are not widely held in U.S. ARL libraries. Titles falling into categories such as leftist/Marxist politics, gay/lesbian, and labor are particularly underrepresented in library holdings, as are titles that are newsletters or magazines. The impact of these low holdings rates on scholars, students, and archival library collections is discussed.
\end{abstract}

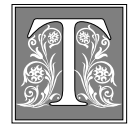

he importance of a free press to democracy is a frequently repeated sentiment among librarians. Articles in library journals often address issues of censorship and the representation of all viewpoints on controversial issues. One aspect of the freedom of the press that has been little discussed, however, is the actual place of the alternative press in library collections. According to Ellen E. Embardo, "alternative publications constitute primary research materials, providing an invaluable record of social and political movements for radical change." ${ }^{1}$ How well are academic libraries meeting the need for scholarly access to alternative press titles? This study uses the list of periodicals indexed by Alternative Press Index to examine the holdings rates of alternative press titles in ARL libraries.

\section{Literature Review \\ Impact of Selection Strategies on Alterna- tive Press Holdings}

Librarians work within limited budgets and must be selective in making periodical purchases. Selection implies some judgment of a periodical's value. One common measure of periodical value is citation rates, which yield numerical measures that can be used to justify the acquisition or cancellation of particular titles. According to Thomas E. Nisonger,

Citation analysis is based on the assumption that documents cited by a researcher have been used in the research process .... Major uses of citation analysis pertinent to collection evaluation include identifying the core collection, using citations as a checklist, ranking journals, and analyzing a discipline's structure to

Rita A. Marinko is a Reference Librarian/Assistant Professor in Parks Library at Iowa State University; e-mail: rmarinko@iastate.edu. Kristin H. Gerhard is a Catalog Librarian/Associate Professor in Parks Library at Iowa State University; e-mail: kgerhard@iastate.edu. 
assist collection management decision making. ${ }^{2}$

It seems logical that citation analysis should allow identification of titles that are absolutely central to a discipline or topic. Thura Mack, for instance, found citation analysis useful in identifying a core of women's studies periodicals, and a number of studies use citation analysis in this way. ${ }^{3}$ But reliance on usage of periodicals as demonstrated through their rate of citation can have a narrowing impact on academic collections.

\section{A periodical that brings a specific viewpoint to a collection thus can have a value that cannot be mea- sured by the frequency with which it is cited.}

Anna H. Perrault's examination of changes in ARL library holdings from 1985 to 1989 revealed a definite increase in homogeneity among these libraries. ${ }^{4}$ Her findings included "a decrease in the percentage of unique titles in many subject areas, and an increased concentration on core materials."

Periodical citation measures are related to factors other than the value of periodical content. For a periodical to be cited, its contents must be made accessible through one or more indexes. That index must be available to researchers. The periodical itself then must be available either locally or through interlibrary loan.

This points up two potential weak links: A periodical may not be indexed or, if indexed, may not be held widely enough to be readily available. First, periodicals that are unindexed are less available to scholars for citation. Indexing increases the likelihood that a periodical will be purchased by libraries because it brings titles to the attention of librarians. This creates a catch-22 situation: A periodical that is unindexed, whether due to newness, content out of the mainstream, or lack of a significant content, is equally unlikely to register on selector librarians' radar. These periodicals are then uncited-their ideas lost to scholars, no matter how relevant the ideas may be to the scholarly enterprise at hand or to society at large.

Second, periodicals that are difficult to obtain cannot be cited. Danny P. Wallace and Bert R. Boyce identified a significant relationship between holdings and some citation measures in some subject areas. ${ }^{5}$ Although the relationship over all eight subjects they examined is variable and sometimes weak, the existence of any relationship at all highlights the difficulties of relying too heavily on citation analysis for broad selection.

\section{Studies of Bias in Library Collections}

A less measurable aspect of periodical value is contained in the ideas it presents. The role of libraries in promoting pluralism is cited often as central to the role of libraries in a democratic society. It is impossible to have a meaningful discussion on issues of the day without access to a broad representation of the viewpoints held in society at large. A periodical that brings a specific viewpoint to a collection thus can have a value that cannot be measured by the frequency with which it is cited. The question of bias in library collections is therefore an important one for a democratic society.

In a preliminary study of bias in collection development, Stephen L. Hupp examined the holdings of liberal and conservative books in the academic, public, and special libraries of Ohio. ${ }^{6}$ Although the focus of this research was on identifying political bias in library collections, Hupp conclude that "the state's libraries have done a poor job in collecting controversial political materials." In his follow-up study, he compared the holdings of five sets of periodical titles, including a set of periodicals representing an alternative perspective. Holdings of alternative periodicals lagged behind holdings 
of liberal or conservative titles. Hupp found that this alternative sample "is represented more fully in public libraries than in academic ... [and] this indicates a greater willingness among such libraries to include these periodical titles in their collections." ${ }^{\prime 7}$ Yet one might expect academic library collections to provide the basis for scholarship and analysis of ideas in a society, and to bring a historical understanding of the development of those ideas.

\section{This research also was designed to determine the relative holdings of alternative press titles in particular subject areas.}

In another examination of the question of bias, this time in the college collection, Robert L. Houbeck Jr. discussed the place of periodicals of opinion in academic libraries. ${ }^{8}$ He found that academic libraries have been "evenhanded" in their selection of periodicals representing conservative and liberal views. He notes:

Those of us in higher education talk frequently about the importance of teaching our students how to think. We also need occasionally to give them something to think about. Journals of opinion fill precisely that role, and in a lively and concise format. We need to provide our students with opportunities to encounter ideas. That means first buying a range of titles such as these. ${ }^{9}$

In a discussion of the Alternative Press Collection at the University of Connecticut, Embardo buttressed this point in her observation that "despite occasional uses of the [Alternative Press Collection] for extensive research, most patrons are students consulting specific titles in preparation for term papers or, more often, are fulfilling a widespread English 109 as- signment requiring the use of 'alternative' viewpoints on contemporary issues. ${ }^{\text {} 10}$

Embardo also points out the time sensitivity of these materials: "once acquired, the material must be swiftly organized and made accessible. The alternative press must be timely to serve those constituencies needing today's questions to provide tomorrow's answers."11 Libraries that lack alternative press titles force scholars to choose between working with a time lag-the time it takes for a published article to be indexed by an indexing service, plus the time to get the article through interlibrary loan-and purchasing personal subscriptions to their research materials.

\section{Research Questions}

This study, rather than comparing conservative and liberal titles in order to identify potential collection bias, looks directly at the alternative press. It asks, How widely are nonmainstream (alternative) periodicals held in academic libraries? That is, to what extent do academic libraries bring nonmainstream ideas to the educational or scholarly table? On the face of it, it seems that periodicals identified as core academic titles were more likely to be in the mainstream, representing widely held social and political views (whether conservative or liberal) than they were to present alternative approaches. If conservative and liberal periodicals of opinion are not widely held by academic libraries, what is the status of alternative periodicals?

This research also was designed to determine the relative holdings of alternative press titles in particular subject areas. It is possible that some topics are better represented than others, and it would be useful for librarians evaluating their collections in terms of bias to be aware of areas of systemic weakness.

\section{Methodology}

The first task was to identify a standard list of alternative press titles whose hold- 
ings could be searched. Alternative Press Index $(A P I)$ is described by one reviewer as a title that "should be part of any collection seeking to offer access to varied points of view."12 At the time of this research, API indexed 220 periodicals. The index itself was held by eighty-eight ARL libraries, or 88 percent, and seemed to be a reasonable source for the identification of periodical titles for this study.

A list of the titles indexed in API was taken from volume 27, no. 1 (1996) of the index. A list of the ARL member libraries as of January 1995 was obtained and OCLC holdings for those libraries identified. Holdings were examined by institution rather than by libraries, so the OCLC holdings symbols for associated law libraries and satellite campuses were added accordingly. All OCLC symbols were acquired from the List of OCLC Participating Institutions.

The symbols were put in order, first by state and then alphabetically by symbol. This arrangement greatly facilitated reading the OCLC holdings printouts because it was only necessary to search through each state's holdings once for the represented libraries.

The researchers searched OCLC by ISSN and by title to gather holdings data. For the purposes of this study, the holdings of a given institution were identified based on the holdings of all its constituent libraries. For example, if a university's law library held a title but its main library did not, the title was counted as held by that institution nonetheless. Because the authors were tallying titles held, and not number of copies held, institutions holding more than one copy of a title were only counted as holding the title once. After compiling holdings information from OCLC printouts, the data were entered into an Excel spreadsheet and the results collated by several variables.

First, the titles were arranged in alphabetical order, and their respective holdings were entered. This allowed the authors to take raw counts of the number of libraries holding any given title and the total API titles held by each library. If this percentage was ten percent or lower, the library was called to ascertain whether serial holdings were placed in OCLC or whether another reason existed for the low percentage. In the case of a few specialized libraries, the area of specialization was such as to logically preclude holding titles from API. For instance, Linda Hall Library collects exclusively in the area of science and technology and, with few exceptions, would not be expected to own the titles covered by this index. In the case of some other libraries, holdings no longer are being added to OCLC, but to RLIN instead. Because the extremely low holdings rates indicated for Canadian ARL libraries would skew the data, they were dropped from the sample, leaving data for the 104 U.S. ARL libraries.

To allow examination of holdings by subject area, titles next were arranged by the subject headings used in API. Because the subject terms used by the index were quite specific, sometimes with only one title for a given heading, headings were clustered into broader groups. These subject clusters are given in table 1 (see pp. 372-374). Because many titles were indexed under multiple subject terms, a sizeable number of the titles ended up in more than one of the broad groupings. Then these clusters were analyzed using an analysis of variance test and grouped into ranges using Duncan's Multiple Range Test (in SAS) to determine if specific subject areas were differentially represented in U.S. ARL libraries' holdings.

Finally, titles were separated into two groups based on their designation in API as journals or newsletters/magazines. Holdings by type of title then were compared to determine if a title's holdings could be related to its format.

\section{Results and Discussion Overall results}

The overall results were discouraging. The percentage of API periodicals held 


\begin{tabular}{|c|c|c|c|c|c|}
\hline \multicolumn{6}{|c|}{$\begin{array}{c}\text { TABLE } 2 \\
\text { Holdings of Alternative Press Titles in U.S. ARL Libraries, by Institution }\end{array}$} \\
\hline $\begin{array}{l}\text { Institution } \\
\text { (OCLC symbol) }\end{array}$ & $\begin{array}{l}\text { Number of } \\
\text { Titles Held }\end{array}$ & $\begin{array}{c}\text { Percent } \\
\text { Held }\end{array}$ & $\begin{array}{l}\text { Institution } \\
\text { (OCLC symbol) }\end{array}$ & $\begin{array}{l}\text { Number of } \\
\text { Titles Held }\end{array}$ & $\begin{array}{c}\text { Percent } \\
\text { Held }\end{array}$ \\
\hline IWA & 59 & $27 \%$ & MUB, UMC, LUM & 112 & 51 \\
\hline NUI, LUI & 115 & 52 & EEM & 140 & 64 \\
\hline AAA & 40 & 18 & EYM, MI & 143 & 65 \\
\hline ABC, ALM, AUL & 61 & 28 & EYW & 73 & 33 \\
\hline AZS, AZC & 87 & 40 & MNU, MLL & 103 & 47 \\
\hline AZU, AZL & 76 & 35 & LHL & 0 & 0 \\
\hline CLU & 146 & 66 & MUU, LMU & 67 & 30 \\
\hline CRU & 51 & 23 & WTU, WUL & 69 & 31 \\
\hline CSL, ZZX & 80 & 36 & NDD, NDL & 103 & 47 \\
\hline CUI & 61 & 28 & NOC, NDO & 102 & 46 \\
\hline CUS & 105 & 48 & NRC & 49 & 22 \\
\hline CUT & 85 & 39 & LDL, LLL & 55 & 25 \\
\hline CUV & 17 & 8 & DRB & 64 & 29 \\
\hline CUY, BOL & 84 & 38 & NJR & 46 & 21 \\
\hline STF & 101 & 46 & PUL & 94 & 43 \\
\hline COD, UCX & 114 & 52 & IQU, NML & 68 & 31 \\
\hline $\mathrm{COF}$ & 72 & 33 & BUF, SBL & 93 & 42 \\
\hline UCW, UCL & 156 & 71 & $\mathrm{COO}$ & 63 & 29 \\
\hline YUS, CXR & 47 & 21 & NAM & 69 & 31 \\
\hline DGU, GUL & 53 & 24 & NYG & 38 & 17 \\
\hline DHU, HLL & 83 & 38 & NYP & 159 & 72 \\
\hline DLC & 148 & 67 & RRR & 66 & 30 \\
\hline SMI & 17 & 8 & SYB, SYL & 90 & 41 \\
\hline DLM & 89 & 40 & YSM & 69 & 31 \\
\hline FDA, FSL & 86 & 39 & ZCU, ZCL & 93 & 42 \\
\hline FQG, FML & 62 & 28 & ZYU, YLS & 11 & 5 \\
\hline FUG, FUB & 87 & 40 & CIN, DML & 67 & 30 \\
\hline EMU, EMK & 64 & 29 & CWR, CWL & 34 & 15 \\
\hline GAT & 18 & 8 & KSU & 48 & 22 \\
\hline GUA,GUB & 82 & 37 & OSU, OHL & 98 & 45 \\
\hline HUH, HLR & 73 & 33 & OKS & 52 & 24 \\
\hline CGU, KEN & 68 & 31 & OKU, OKL & 54 & 25 \\
\hline CRL & 13 & 6 & ORU, UOL & 93 & 42 \\
\hline IAY & 25 & 11 & PAU, PLL & 55 & 25 \\
\hline INU, INL & 98 & 45 & PIT, PLA & 105 & 48 \\
\hline SOI, SOL & 86 & 39 & TEU & 113 & 51 \\
\hline UIU & 95 & 43 & UPM & 103 & 47 \\
\hline IND,XND & 72 & 33 & $\mathrm{RBN}$ & 63 & 29 \\
\hline IPL & 71 & 32 & SUC, SLW & 63 & 29 \\
\hline IUP, IUL, IUB & 118 & 54 & TJC, TJL & 63 & 29 \\
\hline KKU, KFL & 92 & 42 & TKN, TLK & 67 & 30 \\
\hline KUK & 78 & 35 & IXA & 101 & 46 \\
\hline LRU,LRL & 71 & 32 & RCE & 21 & 10 \\
\hline LUU, LUL & 37 & 17 & TXA & 52 & 24 \\
\hline AUM & 82 & 37 & TXH, THL & 49 & 22 \\
\hline BOS, BOP & 63 & 29 & UBY, UTY & 44 & 20 \\
\hline BRL & 28 & 13 & UUM & 78 & 35 \\
\hline HUL, HVL & 133 & 60 & VA@,VAL & 70 & 32 \\
\hline MYG & 59 & 27 & VPI & 73 & 33 \\
\hline AGL & 11 & 5 & NTE & 95 & 43 \\
\hline JHE & 57 & 26 & WAU & 80 & 36 \\
\hline NLM & 3 & 1 & GZM, GZL & 128 & 58 \\
\hline
\end{tabular}




\begin{tabular}{|c|c|c|c|}
\hline \multicolumn{4}{|c|}{$\begin{array}{c}\text { TABLE } 4 \\
\text { Holdings by Subject Clusters (Raw Data) } \\
\end{array}$} \\
\hline Subject Area & $\begin{array}{c}\text { No. of } \\
\text { Titles }\end{array}$ & $\begin{array}{c}\text { Total } \\
\text { Holdings }\end{array}$ & $\begin{array}{l}\text { Aver No. of Holding } \\
\text { Libraries per Title }\end{array}$ \\
\hline Activism & 11 & 175 & 1.6 \\
\hline Animal Rights & 1 & 53 & 0.5 \\
\hline Arts & 12 & 512 & 4.7 \\
\hline Ecology & 20 & 456 & 4.2 \\
\hline Economics & 9 & 323 & 3.0 \\
\hline Education & 9 & 224 & 2.1 \\
\hline Food & 3 & 19 & 0.2 \\
\hline Gay/Lesbian & 5 & 144 & 1.3 \\
\hline Geography/Area Studies & 45 & 1631 & 15.1 \\
\hline Health & 9 & 323 & 3.0 \\
\hline Human Rights & 16 & 606 & 5.6 \\
\hline Intelligence Agencies & 1 & 4 & 0.0 \\
\hline Labor & 8 & 219 & 2.0 \\
\hline Leftist Politics & 38 & 1115 & 10.3 \\
\hline Media & 19 & 773 & 7.2 \\
\hline $\begin{array}{l}\text { Military/Peace/ } \\
\text { International Relations }\end{array}$ & 8 & 152 & 1.4 \\
\hline People & 51 & 2235 & 20.7 \\
\hline $\begin{array}{l}\text { People of Color/ } \\
\text { Native Peoples }\end{array}$ & 11 & 482 & 4.5 \\
\hline $\begin{array}{l}\text { Social Sciences and } \\
\text { Humanities }\end{array}$ & 15 & 710 & 6.6 \\
\hline Sociology & 8 & 538 & 5.0 \\
\hline Sports & 1 & 57 & 0.5 \\
\hline Technology & 3 & 46 & 0.4 \\
\hline Women & 31 & 1522 & 14.1 \\
\hline
\end{tabular}

are presented, by library, in table 2 . The percentage held in a given library varied from zero percent (Linda Hall Library) to 71 percent (University of Connecticut Library) and 72 percent (New York Public Library), with sixty-nine of the libraries' holdings rates below 40 percent. Only twelve libraries had holdings rates above 50 percent.

Individual periodicals' holding rates are given in table 3 (see pp. 375-377). These percentages also varied widely, from zero percent (e.g., Challenge, Journal of Prisoners on Prisons) to 88 percent (The Nation). The spread of holdings rates by title also was clustered toward the lower end. Only thirty-seven titles (17\% of the total 220$)$ were held by 70 percent or more of the libraries studied, whereas 139 of the 220 titles (63\%) were held by less than 40 percent of U.S. ARL libraries.

Some library collections have a very specific focus (e.g., Linda Hall Library, as mentioned above; the National Library of Medicine, etc.). These libraries logically enough do not hold high numbers of alternative press titles. In addition, some of these titles (e.g., Critique: Journal for Critical Studies of the Middle East; Genewatch) are very narrow, and their low rates of holding among ARL libraries as a whole are not that surprising. Nonetheless, the level of access provided to the alternative press in ARL libraries is demonstrably quite low. 


\begin{tabular}{|c|c|c|c|c|c|c|c|c|c|c|c|c|}
\hline \multicolumn{13}{|c|}{$\begin{array}{c}\text { TABLE } 5 \\
\text { Analysis of Holdings by Subject Cluster }\end{array}$} \\
\hline \multicolumn{13}{|c|}{ Duncan Grouping } \\
\hline Subject Category & Mean & A & $\mathrm{B}$ & $\mathrm{C}$ & $\mathrm{D}$ & $\mathrm{E}$ & $\mathrm{F}$ & $\mathrm{G}$ & $\mathrm{H}$ & I & $\mathrm{J}$ & K \\
\hline Sociology & 0.64663 & $\mathrm{X}$ & & & & & & & & & & \\
\hline Sports & 0.54808 & & $\mathrm{X}$ & & & & & & & & & \\
\hline Animal Rights & 0.50962 & & $\mathrm{X}$ & $\mathrm{X}$ & & & & & & & & \\
\hline Women & 0.47208 & & & $\mathrm{X}$ & $\mathrm{X}$ & & & & & & & \\
\hline Arts & 0.41026 & & & & $\mathrm{X}$ & $\mathrm{X}$ & & & & & & \\
\hline $\begin{array}{l}\text { People of Color/ } \\
\text { Native Peoples }\end{array}$ & 0.40734 & & & & $\mathrm{X}$ & $\mathrm{X}$ & $\mathrm{X}$ & & & & & \\
\hline $\begin{array}{l}\text { Social Sciences } \\
\text { and Humanities }\end{array}$ & 0.39744 & & & & & $\mathrm{X}$ & $\mathrm{X}$ & & & & & \\
\hline People & 0.39461 & & & & & $\mathrm{X}$ & $\mathrm{X}$ & & & & & \\
\hline Media & 0.39119 & & & & & $\mathrm{X}$ & $\mathrm{X}$ & & & & & \\
\hline Human Rights & 0.36418 & & & & & $\mathrm{X}$ & $\mathrm{X}$ & & & & & \\
\hline Economics & 0.34509 & & & & & $\mathrm{X}$ & $\mathrm{X}$ & $\mathrm{X}$ & & & & \\
\hline $\begin{array}{l}\text { Geography/Area } \\
\text { Studies }\end{array}$ & 0.33269 & & & & & & $\mathrm{X}$ & $X$ & $\mathrm{X}$ & & & \\
\hline $\begin{array}{l}\text { Leftist/Marxist } \\
\text { Politics }\end{array}$ & 0.28214 & & & & & & & $\mathrm{X}$ & $\mathrm{X}$ & $\mathrm{X}$ & & \\
\hline Gay/Lesbian & 0.27692 & & & & & & & $X$ & $\mathrm{X}$ & $\mathrm{X}$ & & \\
\hline Labor & 0.26322 & & & & & & & & $\mathrm{X}$ & $\mathrm{X}$ & & \\
\hline Education & 0.26068 & & & & & & & & $\mathrm{X}$ & $\mathrm{X}$ & & \\
\hline Ecology & 0.21923 & & & & & & & & & $\mathrm{X}$ & $\mathrm{X}$ & \\
\hline $\begin{array}{l}\text { Military/Peace } \\
\text { Studies/ } \\
\text { International } \\
\text { Relations }\end{array}$ & 0.17188 & & & & & & & & & & $\mathrm{X}$ & \\
\hline Health & 0.16827 & & & & & & & & & & $\mathrm{X}$ & \\
\hline Activism & 0.15297 & & & & & & & & & & $\mathrm{X}$ & \\
\hline Technology & 0.14742 & & & & & & & & & & $\mathrm{X}$ & \\
\hline Food & 0.06090 & & & & & & & & & & & $\mathrm{X}$ \\
\hline Intelligence & 0.03846 & & & & & & & & & & & $\mathrm{X}$ \\
\hline
\end{tabular}

\section{Results by Subject}

The authors' questions about holdings by subject proved to be well founded. They discovered a fairly wide variance in holdings among the subject clusters. The raw data are given in table 4, and the results of the Duncan's Multiple Range Test are given in table 5 .

Table 5 presents the subject categories in order, from those most likely to be held to those least likely to be held. There were significant differences in holdings rates for the different subject categories. Categories sharing one or more Duncan
Grouping, indicated by $\mathrm{X}$ in the righthand columns, were not significantly different from one another. For example, the titles in the category of Women had a holdings rate that was not significantly different from the holdings rate for titles in the category of Arts, as both are in the D group. But there are significant differences between the holdings rate for the titles in the Women category $(C, D)$ and the holdings rate for titles in Sociology (A only).

Some of the categories near the bottom contained so few titles that it is difficult 


\begin{tabular}{|l} 
TABLE 6 \\
Difference between Journal and Newsletter/ \\
Magazine Holdings Rates \\
Analysis of Variance
\end{tabular}

hardly an astonishing discovery but at the very least raises concern about archiving for future research uses.

\section{Conclusion}

Periodicals that are indexed, but not held, require that library users be willing to request desired articles through some form of document delivery and then to wait for them to arrive. Holding API to come to meaningful conclusions about their holdings rates. But it also is clear from these data that periodicals in certain categories consistently are underrepresented in U.S. ARL library collections, even within the ranks of alternative periodicals. Titles in the areas of leftist/Marxist politics, gay and lesbian titles, and alternative titles in labor, education, and ecology are all underrepresented. This reinforces the findings of Hupp and undermines somewhat the political claim that American universities are hotbeds of radical leftist thought.

\section{Results by Type of Publication}

A comparison of the holdings rates for journals and newsletters/magazines in the sample revealed that libraries were significantly more likely to collect journals than newsletters (see table 6). This is

is one step toward providing access, but holding the periodical locally is another. In addition, when a periodical is held rarely, from where will we get that document delivered?

Further research needs to be conducted on the feasibility of expanding our national holdings of these titles, perhaps through a cooperative regional approach to collection development. The least-represented topical areas in particular need to be examined if we are to work toward representing all viewpoints in libraries. For alternative views to contribute to the democratic discussion in our society, these ideas at least must be available to those wrestling with the problems and issues of that society. The periodicals representing these ideas must not only be indexed, but also must be held in research library collections.

\section{Notes}

1. Ellen E. Embardo, “The Alternative Press Collection, University of Connecticut," Library Quarterly 59, no. 1 (1989): 55-63.

2. Thomas E. Nisonger, Collection Evaluation in Academic Libraries: A Literature Guide and Annotated Bibliography (Englewood, Colo.: Libraries Unlimited, 1992), 98.

3. Thura Mack, "A Model Methodology for Selecting Women"s Studies Core Journals," Library and Information Science Research 13, no. 2 (1991): 131-45.

4. Anna H. Perrault, The Changing Print Resource Base of Academic Libraries in the United States: A Comparison of Collection Patterns in Seventy-Two ARL Academic Libraries of Non-Serial Imprints for the Years 1985 and 1989 (Ph.D. diss., Florida State University, 1994), xi.

5. Danny P. Wallace and Bert R. Boyce, "Holdings As a Measure of Journal Value," Library and Information Science Research 11, no. 1 (1989): 59-71.

6. Stephen L. Hupp, "The Left and the Right: A Preliminary Study of Bias in Collection Development in Ohio Libraries," Collection Management 14, no. 2 (1991): 139-54.

7. - "The Left and the Right: A Follow-Up Survey of the Collection of Journals of Political Opinion in Ohio Libraries," Collection Management 18, no. 2 (1993): 135-52. 
8. Robert L. Houbeck Jr., "Locked in Conversation: The College Library Collection and the Pluralist Society," Journal of Library Administration 17, no. 2 (1992): 99-131.

9. Ibid., 127.

10. Embardo, "The Alternative Press Collection, University of Connecticut," 62.

11. Ibid., 61.

12. Marie F. Jones. Review of Alternative Press Index. Library Journal 117, no. 14 (Sept. 1, 1992): p. 166. 


\section{TABLE 1}

\section{Alternative Press Periodical Titles by Subject Cluster}

\begin{tabular}{l}
\hline Activism (11 titles) \\
\hline Subject headings: organizing, \\
housing, citizen activism, political \\
activism, boycotts, economic \\
alternatives \\
Boycott Quarterly \\
Breakthrough \\
City Limits \\
Common Cause \\
Co-Op America Quarterly \\
Grassroots Fundraising Journal \\
Neighborhood Works \\
Organizing \\
Public Citizen \\
Shelterforce \\
Third Force \\
$\quad$ Animal Rights (1 title) \\
\hline
\end{tabular}

Subject heading: animal rights

Animals' Agenda

The Arts (12 titles)

Subject headings: literature, art,

film, culture \& politics

Borderlines

Camera Obscura

Cineaste

Critical Arts

Fuse

Heresies

Independent

Jump Cut

Lambda Book Report

Left Curve

Red Bass

Women's Review of Books

Ecology (20 titles)

Subject headings: energy, environment, left ecology, social ecology, environmental justice

Alternatives (Ontario, Canada)

Amicus Journal

Bogong (no OCLC record)

Capitalism, Nature, Socialism

Chain Reaction

E: The Environmental Magazine

Earth First!

Earth Island Journal

Ecologist

Environmental Action

Friends of the Earth

New Catalyst

No Sweat News (no OCLC record) (ecology cont.)

Permaculture Activist (no OCLC

record)

Powerline

Raise the Stakes

Raw Materials Report

Society and Nature

Women and Environments

The Workbook (no OCLC record)

\begin{tabular}{l} 
Economics (9 titles) \\
\hline Subject headings: economics, \\
business, World Bank, political \\
economy \\
Bankcheck \\
Business Ethics \\
Capital and Class \\
Dollars and Sense \\
Economic Notes \\
Left Business Observer \\
Review of African Political \\
Economy \\
Review of Radical Political \\
Economics \\
Studies in Political Economy
\end{tabular}

Education (9 titles)

Subject headings: education, library studies

Critical Arts

Feminist Teacher

Holistic Education Review

Our Schools/Ourselves

Progressive Librarian

Radical Teacher

Rethinking Schools

Women's Education/Education des

Femmes

Women's Studies Quarterly

\begin{tabular}{l} 
Food (3 titles) \\
\hline Subject headings: agriculture, \\
vegetarianism, food \\
Permaculture Activist (no OCLC \\
record) \\
Vegetarian Voice \\
World Hunger Year \\
$\quad$ Gay/Lesbian ( 5 titles)
\end{tabular}

Subject headings: gay/lesbian

Advocate

BLK

Lambda Book Report

Lesbian Contradiction

RFD
Geography/Area Studies (45 titles)

Subject headings: regional, Africa, Canada, Australia, Cuba, Asia/South Asia, England, Middle East, Iran, South Africa, Latin America, third world, Eastern Europe, geography

Africa News

Alternatives (Ontario, Canada)

Antipode

Atlantis

Australian Feminist Studies

Bogong (no OCLC record)

Borderlines

Briarpatch

Bulletin of Concerned Asian

Scholars

Canadian Dimension

Capital and Class

Chain Reaction

Challenge (no OCLC record)

Chartist

Critical Arts

Critique: Journal of Critical

Studies of the Middle East

Cuba Update

Feminist Review

Free Associations

Hecate

History Workshop

Journal of Palestine Studies

Kick It Over

Kinesis

Labor, Capital and Society

Labor/Le Travail

Latin American Perspectives

Middle East Report

NACLA: A Report on the

Americas

New Catalyst

New Left Review

New Maritimes

Our Schools/Ourselves

Our Times

Peace \& Democracy

Race and Class

Review of African Political

Economy

Science as Culture

South Asia Bulletin

Southern Exposure 
TABLE 1 (cont.)

\section{Alternative Press Periodical Titles by Subject Cluster}

Studies in Political Economy

Theory, Culture \& Society

This Magazine

Women and Environments

Women's Education/Education Des

Femmes

Health (2 titles)
Subject headings: health, alternative
culture
Mothering
Nutrition Action Healthletter

Human Rights (16 titles)
Subject headings: law, civil rights,
human rights, disability rights,
prisoners

Berkeley Women's Law Journal

California Prisoner

Covert Action Quarterly

Disability Rag

Guild Notes

Harvard Women's Law Journal

Human Rights Internet Reporter

Index on Censorship

Journal of Prisoners on Prisons

Mouth

Our Right to Know

Prison News

Rights/Bill of Rights Journal

Social Justice

Women and Criminal Justice

Women's Rights Law Reporter

\section{Intelligence Agencies (1 title)}

Subject heading: intelligence agencies

Unclassified

$$
\text { Labor (8 titles) }
$$

Subject headings: labor, interna-

tional labor, IWW, and OHS

Beyond Borders

Industrial Worker

Labor History

Labor Notes

Labor Research Review

Labor/Le Travail

New Solutions

Our Times

\begin{tabular}{l} 
Leftist/Marxist Politics (38 titles) \\
\hline Subject headings: Worker's World \\
Party, CPUSA, DSA, Second \\
International, Political Theory,
\end{tabular}

Political Analysis, SWP-England, International Viewpoint

Fourth International, Marxist

Theory/Marxism, Solidarity,

Anarchy/Anarchism, Anarchism

\&Libertarian Socialism, World

Poverty, Socialist Analysis, Socio-

Political Analysis, Socialism

Against the Current

Anarchy (no OCLC record)

Antipode

Briarpatch

Bulletin in Defense of Marxism

Chartist

Constellations

Critique (Glasgow, Scotland)

Crossroads

Democratic Left

Dissent

Fifth Estate

Forward Motion

International Socialism

International Viewpoint

Kick It Over

Left Curve

Liberation and Marxism

Monthly Review

Nature, Society, and Thought

New Internationalist

New Left Review

New Political Science

New Politics

Our Generation

Political Affairs

Leftist/Marxist Politics cont.

Radical America

Red Pepper

Rethinking Marxism

Science and Society

Social Alternatives

Social Anarchism

Social Text

Socialism and Democracy

Socialist Affairs

Socialist Review

Toward Freedom

Z Magazine

$$
\text { Media (19 titles) }
$$

Subject headings: alternative press, alternative media, media, news, international news and analysis

Alternative Press Review

Community Media Review

Extra

In These Times
Lies of Our Times

Media \& Values

Mother Jones

Multinational Monitor

Nation

On the Issues

Progressive

Propaganda Review

Sipapu

St. Louis Journalism Review

This Magazine

Toward Freedom

Utne Reader

Z Magazine

$$
\begin{gathered}
\text { Military/Peace/International } \\
\text { Relations (8 titles) }
\end{gathered}
$$

Subject headings: active duty GI, veterans, antidraft, peace, international relations

Nonviolent Activist

On Guard

Peace \& Democracy

Peace \& Freedom

Peace Magazine

Peace News

Reconciliation International

World Policy Journal

People (51 titles)

Subject headings: native peoples, Native American, alternative culture, multiculturalism, gay/ lesbian, people of color, Black, Jewish culture, seniors, working women, women, women's history

Abya Yala News

Advocate

Akwe:Kon Journal

Akwesasne Notes

Atlantis

Australian Feminist Studies

Berkeley Women's Law Journal

Black Scholar

BLK

Camera Obscura

Changing Men

Colors

Connexions

Cultural Survival Quarterly

Daybreak

Feminist Issues

Feminist Studies 
TABLE 1 (cont.)

\section{Alternative Press Periodical Titles by Subject Cluster}

Feminist Teacher

Gray Panther Network

Harvard Women's Law Journal

Hecate

Heresies

Hypatia

In Context

Journal of Women $=\mathrm{s}$ History

Kick It Over

Kinesis

Lambda Book Report

Lesbian Contradiction

Mothering

Off Our Backs

On the Issues

Peace \& Freedom

Race and Class

RFD

Sage: A Scholarly Journal on Black

Women

Third Force

Tikkun

Tradeswomen

Trivia

Whole Earth Review

Women and Criminal Justice

Women and Environments

Women and Therapy

Women in Action

Women's Education/Education Des

Femmes

Women's Review of Books

Women's Rights Law Reporter

Women's Studies International

Forum

Women's Studies Quarterly

Women's World

People of Color/Native Peoples (11 titles)

Subject headings: people of color, native peoples

Abya Yala News

Akwe:Kon Journal

Akwesasne Notes

Black Scholar
BLK

Colors

Cultural Survival Quarterly

Daybreak

Race and Class

Sage: A Scholarly Journal on Black

Women

Third Force

Social Sciences and Humanities (15 titles)

Subject headings: anthropology, cultural studies, history, psychology, philosophy, urbanism, religion American Atheist

Critique of Anthropology

Cultural Survival Quarterly

Free Associations

History Workshop

Hypatia

Journal of Urban and Cultural

Studies

Labor History

Labor/Le Travail

Practice

Radical History Review

Radical Philosophy Review of

Books

Sojourners

Thesis Eleven

Women and Therapy

Sociology (8 titles)
Subject headings: social policy,
social theory, sociology, sociology
and social work

Alternatives (Boulder, Colo.)

Berkeley Journal of Sociology

Critical Sociology

Journal of Progressive Human

Services

Social Justice

Social Policy

Theory, Culture \& Society

Thesis Eleven
Subject heading: sports

Journal of Sport and Social Issues

Technology (3 titles)

Subject headings: technology and society, biotechnology

Genewatch

Processed World

Science as Culture

Subject heading: women

Atlantis

Australian Feminist Studies

Berkeley Women's Law Journal

Camera Obscura

Connexions

Feminist Issues

Feminist Review

Feminist Studies

Feminist Teacher

Harvard Women's Law Journal

Hecate

Heresies

Hypatia

Kick It Over

Kinesis

Mothering

Off Our Backs

On The Issues

Peace \& Freedom

Sage: A Scholarly Journal on Black Women

Trivia

Women and Criminal Justice

Women and Environments

Women and Therapy

Women in Action

Women's Education/Education des

Femmes

Women's Review of Books

Women's Rights Law Reporter

Women's Studies International

Forum

Women's Studies Quarterly

Women's World

Sports (1 title) 


\begin{tabular}{|c|c|c|c|c|c|}
\hline \multicolumn{6}{|c|}{$\begin{array}{c}\text { TABLE } 3 \\
\text { Holdings in U.S. ARL Libraries, by Periodical Title }\end{array}$} \\
\hline \multirow{2}{*}{$\begin{array}{l}\text { Periodical } \\
\text { Title }\end{array}$} & \multicolumn{2}{|c|}{ Holdings } & \multirow{2}{*}{$\begin{array}{l}\text { Periodical } \\
\text { Title }\end{array}$} & \multicolumn{2}{|c|}{ Holdings } \\
\hline & Total & Percentage & & Total & Percentage \\
\hline Abya Yala News & 19 & $18 \%$ & City Limits & 15 & 14 \\
\hline Advocate & 70 & 67 & Co-Op America Quarterly & 6 & 6 \\
\hline Africa News & 55 & 53 & Colors & 4 & 4 \\
\hline Against the Current & 25 & 24 & Common Cause & 68 & 65 \\
\hline Akwe:Kon Journal & 27 & 26 & Community Media Review & 3 & 3 \\
\hline Akwesasne Notes & 67 & 64 & Connexions & 52 & 50 \\
\hline Alternative Press Review & 6 & 6 & Constellations & 59 & 57 \\
\hline Alternatives (Boulder, Col.) & 79 & 76 & Covert Action Quarterly & 34 & 33 \\
\hline Alternatives (Ontario, & 34 & 33 & Critical Arts & 23 & 22 \\
\hline Canada) & & & Critical Sociology & 78 & 75 \\
\hline American Atheist & 29 & 28 & Critique (Glasgow, & 45 & 43 \\
\hline Amicus Journal & 74 & 71 & Scotland) & & \\
\hline Anarchy (no OCLC record) & 0 & 0 & Critique of Anthropology & 66 & 63 \\
\hline Animals' Agenda & 53 & 51 & Critique: Journal for & 14 & 13 \\
\hline Antipode & 66 & 63 & Critical Studies of the & & \\
\hline Atlantis & 37 & 36 & Middle East & & \\
\hline Australian Feminist Studies & 30 & 29 & Crossroads & 14 & 13 \\
\hline Bankcheck & 4 & 4 & Cuba Update & 32 & 31 \\
\hline Berkeley Journal of & 81 & 78 & Cultural Survival Quarterly & 65 & 63 \\
\hline Sociology & & & Daybreak & 9 & 9 \\
\hline Berkeley Women's Law & 58 & 56 & Democratic Left & 25 & 24 \\
\hline Journal & & & Disability Rag & 9 & 9 \\
\hline Beyond Borders & 3 & 3 & Dissent & 89 & 86 \\
\hline Black Scholar & 88 & 85 & Dollars and Sense & 46 & 44 \\
\hline BLK & 17 & 16 & E: The Environmental & 26 & 25 \\
\hline Bogong (no OCLC record) & 0 & 0 & Magazine & & \\
\hline Borderlines & 11 & 11 & Earth First! & 14 & 13 \\
\hline Boycott Quarterly & 4 & 4 & Earth Island Journal & 18 & 17 \\
\hline Breakthrough & 15 & 14 & Ecologist & 80 & 77 \\
\hline Briarpatch & 5 & 5 & Economic Notes & 29 & 28 \\
\hline Bulletin in Defense & 1 & 1 & Environmental Action & 66 & 63 \\
\hline of Marxism & & & Extra & 29 & 28 \\
\hline Bulletin of Concerned & 71 & 68 & Feminist Issues & 75 & 72 \\
\hline Asian Scholars & & & Feminist Review & 71 & 68 \\
\hline Business Ethics & 17 & 16 & Feminist Studies & 90 & 87 \\
\hline California Prisoner & 10 & 10 & Feminist Teacher & 48 & 46 \\
\hline Camera Obscura & 71 & 68 & Fifth Estate & 18 & 17 \\
\hline Canadian Dimension & 38 & 37 & Forward Motion & 2 & 2 \\
\hline Capital and Class & 50 & 48 & Free Associations & 17 & 16 \\
\hline Capitalism, Nature & 30 & 29 & Friends of the Earth & 21 & 20 \\
\hline Socialism & & & Fuse & 10 & 10 \\
\hline Chain Reaction & 2 & 2 & Genewatch & 8 & 8 \\
\hline Challenge (no OCLC record & d) 0 & 0 & Grassroots Fundraising & 8 & 8 \\
\hline Changing Men & 31 & 30 & Journal & & \\
\hline Chartist & 5 & 5 & Gray Panther Network & 13 & 13 \\
\hline Cineaste & 77 & 74 & Guild Notes & 29 & 28 \\
\hline
\end{tabular}




\begin{tabular}{|c|c|c|c|c|c|}
\hline \multicolumn{6}{|c|}{$\begin{array}{c}\text { TABLE } 3 \\
\text { Holdings in U.S. ARL Libraries, by Periodical Title }\end{array}$} \\
\hline \multirow{2}{*}{$\begin{array}{l}\text { Periodical } \\
\text { Title }\end{array}$} & \multicolumn{2}{|c|}{ Holdings } & \multirow{2}{*}{$\begin{array}{l}\text { Periodical } \\
\text { Title }\end{array}$} & \multicolumn{2}{|c|}{ Holdings } \\
\hline & Total & Percentage & & Total & Percentage \\
\hline Harvard Women's & 68 & 65 & Mother Jones & 91 & 88 \\
\hline Law Journal & & & Mothering & 7 & 7 \\
\hline Hecate & 33 & 32 & Mouth & 4 & 4 \\
\hline Heresies & 73 & 70 & Multinational Monitor & 59 & 57 \\
\hline History Workshop & 82 & 79 & NACLA: Report on the & 42 & 40 \\
\hline Holistic Education Review & 14 & 13 & Americas & & \\
\hline Human Rights Internet & 52 & 50 & Nation & 92 & 88 \\
\hline Reporter & & & Nature, Society, and & 17 & 16 \\
\hline Hypatia & 81 & 78 & Thought & & \\
\hline In Context & 11 & 11 & Neighborhood Works & 13 & 13 \\
\hline In These Times & 70 & 67 & New Catalyst & 1 & 1 \\
\hline Independent & 27 & 26 & New Internationalist & 37 & 36 \\
\hline Index on Censorship & 76 & 73 & New Left Review & 89 & 86 \\
\hline Industrial Worker & 22 & 21 & New Maritimes & 2 & 2 \\
\hline International Socialism & 9 & 9 & New Political Science & 50 & 48 \\
\hline International Viewpoint & 6 & 6 & New Politics & 70 & 67 \\
\hline Journal of Palestinian & 82 & 79 & New Solutions & 6 & 6 \\
\hline Studies & & & No Sweat News & 0 & 0 \\
\hline Journal of Prisoners on & 0 & 0 & Nonviolent Activist & 15 & 14 \\
\hline Prisons & & & Nutrition Action & 28 & 27 \\
\hline Journal of Progressive & 34 & 33 & Healthletter & & \\
\hline Human Services & & & Off Our Backs & 60 & 58 \\
\hline Journal of Sport and & 57 & 55 & On Guard & 3 & 3 \\
\hline Social Issues & & & On the Issues & 23 & 22 \\
\hline $\begin{array}{l}\text { Journal of Urban and } \\
\text { Cultural Studies }\end{array}$ & 4 & 4 & $\begin{array}{l}\text { Organizing (OCLC record, } \\
\text { no holdings) }\end{array}$ & 0 & 0 \\
\hline Journal of Women's & 80 & 77 & Our Generation & 8 & 8 \\
\hline History & & & Our Right to Know & 4 & 4 \\
\hline Jump Cut & 70 & 67 & Our Schools/Ourselves & 2 & 2 \\
\hline Kick It Over & 6 & 6 & Our Times & 2 & 2 \\
\hline Kinesis & 6 & 6 & Peace \& Democracy & 8 & 8 \\
\hline Labor History & 90 & 87 & Peace \& Freedom & 10 & 10 \\
\hline Labor Notes & 20 & 19 & Peace Magazine & 5 & 5 \\
\hline Labor Research Review & 33 & 32 & Peace News & 18 & 17 \\
\hline Labour, Capital and Society & 32 & 31 & Permaculture Activist & 0 & 0 \\
\hline Labour/Le Travail & 43 & 41 & Political Affairs & 7 & 7 \\
\hline Lambda Book Report & 37 & 36 & Powerline & 10 & 10 \\
\hline Latin American Perspectives & es 81 & 78 & Practice & 8 & 8 \\
\hline Left Business Observer & 9 & 9 & Prison News & 3 & 3 \\
\hline Left Curve & 17 & 16 & Processed World & 7 & 7 \\
\hline Lesbian Contradiction & 6 & 6 & Progressive & 86 & 83 \\
\hline Liberation and Marxism & 5 & 5 & Progressive Librarian & 20 & 19 \\
\hline Lies of Our Times & 33 & 32 & Propaganda Review & 17 & 16 \\
\hline Media \& Values & 20 & 19 & Public Citizen & 15 & 14 \\
\hline Middle East Report & 63 & 61 & Race and Class & 85 & 82 \\
\hline Monthly Review & 84 & 81 & Radical America & 68 & 65 \\
\hline
\end{tabular}




\begin{tabular}{|c|c|c|c|c|c|}
\hline \multicolumn{6}{|c|}{$\begin{array}{c}\text { TABLE } 3 \\
\text { Holdings in U.S. ARL Libraries, by Periodical Title } \\
\end{array}$} \\
\hline \multirow{2}{*}{$\begin{array}{l}\text { Periodical } \\
\text { Title }\end{array}$} & \multicolumn{2}{|c|}{ Holdings } & \multirow{2}{*}{$\begin{array}{l}\text { Periodical } \\
\text { Title }\end{array}$} & \multicolumn{2}{|c|}{ Holdings } \\
\hline & Total & Percentage & & Total & Percentage \\
\hline Radical History Review & 88 & 85 & Southern Exposure & 74 & 71 \\
\hline $\begin{array}{l}\text { Radical Philosophy } \\
\text { Review of Books }\end{array}$ & 3 & 3 & $\begin{array}{l}\text { St. Louis Journalism } \\
\text { Review }\end{array}$ & 25 & 24 \\
\hline Radical Teacher & 44 & 42 & Studies in Political & 24 & 23 \\
\hline Raise the Stakes & 8 & 8 & Economy & & \\
\hline Raw Materials Report & 12 & 12 & Theory, Culture \& Society & 72 & 69 \\
\hline Reconciliation International & al 1 & 1 & Thesis Eleven & 34 & 33 \\
\hline Red Bass & 18 & 17 & Third Force & 11 & 11 \\
\hline Red Pepper & 2 & 2 & This Magazine & 48 & 46 \\
\hline Rethinking Marxism & 58 & 56 & Tikkun & 62 & 60 \\
\hline Rethinking Schools & 10 & 10 & Toward Freedom & 10 & 10 \\
\hline Review of African & 64 & 62 & Tradeswomen & 9 & 9 \\
\hline Political Economy & & & Trivia & 39 & 38 \\
\hline Review of Radical & 80 & 77 & Unclassified & 4 & 4 \\
\hline Political Economics & & & Utne Reader & 77 & 74 \\
\hline RFD & 14 & 13 & Vegetarian Voice & 7 & 7 \\
\hline Rights/Bill of Rights & 73 & 70 & Whole Earth Review & 59 & 57 \\
\hline Journal & & & Women and Criminal Justice & $\operatorname{ce} 38$ & 37 \\
\hline Sage: A Scholarly Journal & 74 & 71 & Women and Environments & 51 & 49 \\
\hline on Black Women & & & Women and Therapy & 64 & 62 \\
\hline Science and Society & 19 & 18 & Women in Action & 25 & 24 \\
\hline Science as Culture & 31 & 30 & Women's Education/ & 2 & 2 \\
\hline Shelterforce & 20 & 19 & Education des Femmes & & \\
\hline Sipapu & 43 & 41 & Women's Review of Books & 78 & 75 \\
\hline Social Alternatives & 10 & 10 & Women's Rights Law & 71 & 68 \\
\hline Social Anarchism & 15 & 14 & Reporter & & \\
\hline Social Justice & 77 & 74 & Women's Studies & 83 & 80 \\
\hline Social Policy & 83 & 80 & International Forum & & \\
\hline Social Text & 78 & 75 & Women's Studies Quarterly & 81 & 78 \\
\hline Socialism and Democracy & 37 & 36 & Women's World & 17 & 16 \\
\hline Socialist Affairs & 19 & 18 & Workbook & 0 & 0 \\
\hline Socialist Review & 5 & 5 & World Hunger Year & 12 & 12 \\
\hline Society and Nature & 9 & 9 & World Policy Journal & 83 & 80 \\
\hline Sojourners & 36 & 35 & Z Magazine & 35 & 34 \\
\hline South Asia Bulletin & 45 & 43 & & & \\
\hline
\end{tabular}

